\title{
Reading the mindset of the secretary of state: shaping policy delivery effectiveness
}

Article

Accepted Version

Kakabadse, A. P. and Kakabadse, N. ORCID:

https://orcid.org/0000-0002-9517-8279 (2020) Reading the mindset of the secretary of state: shaping policy delivery effectiveness. British Politics. ISSN 1746-918X doi: https://doi.org/10.1057/s41293-020-00147-3 Available at https://centaur.reading.ac.uk/93412/

It is advisable to refer to the publisher's version if you intend to cite from the work. See Guidance on citing.

Published version at: http://dx.doi.org/10.1057/s41293-020-00147-3

To link to this article DOI: http://dx.doi.org/10.1057/s41293-020-00147-3

Publisher: Springer

All outputs in CentAUR are protected by Intellectual Property Rights law, including copyright law. Copyright and IPR is retained by the creators or other copyright holders. Terms and conditions for use of this material are defined in the End User Agreement.

\section{www.reading.ac.uk/centaur}

\section{CentAUR}

Central Archive at the University of Reading 
Reading's research outputs online 


\title{
Reading the Mindset of the Secretary of State:
}

\section{Shaping Policy Delivery Effectiveness}

\author{
by
}

\author{
Andrew P Kakabadse \\ Professor of Governance and Leadership \\ Henley Business School \\ Greenlands \\ Henley on Thames \\ RG9 3AU \\ Email: a.kakabadse@henley.ac.uk \\ Tel: 01491418770 \\ and \\ Nada Kakabadse \\ Professor of Policy Governance and Ethics \\ Henley Business School \\ Greenlands \\ Henley on Thames \\ RG9 3AU \\ Email: n.kakabadse@henley.ac.uk
}




\title{
Reading the Mindset of the Secretary of State: Shaping Policy Delivery Effectiveness
}

\begin{abstract}
This paper examines the nature of the relationship between the Secretary of State and the Permanent Secretary, with particular focus on determining how policy delivery can be enhanced. The review of the literature offers insights into the role and tasks of the Secretary of State and Permanent Secretary, concluding that the quality of their relationship is central to effective policy delivery. The study reported in this paper surfaces the considerable attention given by public officials to understanding the Secretary of State in order to ensure for better engagement with their political masters. Towards this end, civil servants report that appreciating the Minister's propensity for drawing on evidence (soft or hard data) and their level of personal confidence (feeling secure or insecure) provides for the necessary insights to 'get on to the Minister's wavelength'. Officials report the extent of their flexibility to position arguments in order to win the Minister's attention and approval. The paper concludes that the appropriate (or inappropriate) reading of the Minister is fundamental to enhancing (or damaging) policy delivery. The lengths officials go to so that the Secretary of State can, and can be seen to, appropriately deliver policy seemingly goes unrecognized by the Minister.
\end{abstract}

\section{Keywords}

Secretary of State; Permanent Secretary; policy delivery; use of evidence; personal confidence; reading the Minister 


\section{Reading the Mindset of the Secretary of State: Shaping Policy Delivery Effectiveness}

\section{Introduction}

Traditionally civil servants have been considered as the Minister's principal advisers and, at times, the only advisers on matters of policy and administrative reform, all for the purpose of 'increasing efficiency' and 'cutting costs' whilst meeting the requirements of private individuals and 'citizen consumers' (Seddon, 2014). The act of every civil servant is by convention regarded, 'as the act of his/her Minister' (Jennings, 1952: 189-190).

In recognition of its critical importance, the Minister-civil servant relationship has received scrutiny, particularly on the delineation of the various responsibilities of each party and the quality of interaction and relationship between the two (Morrison, 1954). Morrison (1954: 318 319) identifies the relationship between the Minister and civil servant as one of partnership, shaped by the requirements of accountability in a democracy, 'that of colleagues working together in a team, ... on the understanding, of course, that the Minister's decision is final...'. In order to provide continued efficient and energetic service, the additional values of integrity, fearlessness, and independence of thought and utterance in their private communication with Ministers were seen as 'an essential principle in enlightened Government' (Tomlin, 1931: 1268, para. 12).

Yet such prerequisites reflect a bygone era. The Minister-civil servant relationship, although critical, has undergone many changes (Jary, 2014). It has become more complex, particularly in the post-new public management (NPM) era, often referred to as New Public Governance (NPG), which has led to increasingly complex arrangements in order to ensure that the 
accountability of officials is evident when delivering government policies. The NPG reforms, designed to strengthen the central political administrative levels through structural integration, have modified, but not transformed, this critical relationship (Christensen and Lægreid, 2012). Overall, NPG is in line with previous NPM reforms intensifying political control over the state and the erosion of bureaucratic hierarchies (Rhodes, 2016; Diamond, 2019; Peters, 2013; Aucoin, 2012).

In the past, civil servants exercised considerable influence on public affairs within the constitutional, political, and practical limitations of their authority (Chapman, 2004; Theakston, 1999). In the 21 st century government departments, under the care of the newly constituted departmental boards, chaired by relevant ministers and including non-executive directors (NEDs) drawn from business and public service entities, required civil servants to work with the Minister, with such boards and with special political advisers (SpAds) who become, at times, more influential than senior civil servants and even the Minister (Grube, 2015).

It is, therefore, no surprise that a number of studies have examined various aspects of the Permanent Secretary's job in terms of gender, background, education (Richards, 1997; Greer and Jarman, 2010), the nature of the career experience, the number and length of working relationships with Secretaries of State (Ribbins and Sherratt, 2014), and tenure (Kogan, 1971; Theakston and Fry, 1989; Ribbins and Sherratt, 2014). In a similar vein, other studies have scrutinized various aspects of the ministerial role, the spread and shape of the ministerial office (Morrison, 1954; Brazier, 1997), the legislative impact of Peers (Cowley and Melhuish, 1997), the need for technical competence as a minister (Blondel, 1985), the junior ministers' role (McMaster and Bairner, 2012), and the overall role and contribution of the Minister of the Crown (Barratt, 2015; Kakabadse and Kakabadse, 2011). Further, a number of studies have 
been pursued on how to work with ministers (Jary, 2014; Ribbins and Sherratt, 2014) and on how civil servants provide for relevant and politically sensitive policy advice (Cunnigham, 1963; Bakvis, 1997).

In this paper, we examine the nature of political-administrative interactions at the apex of the UK government from the perspective of efficient and effective policy delivery (Cooper, 2019). Our study examines the blockages, hindrances, and strengths of the Minister-civil servant relationship with particular focus on policy delivery. We examine how the Secretary of State and Permanent Secretary interact and ask how the various agendas in the policy delivery process are pursued.

Attention is given to two different agendas in policy delivery: the urgency of the Minister to execute policy and the realistic appraisal undertaken by civil servants of the blockages and hindrances to be overcome in order to realize effective policy delivery. Analysis of the thinking underlying Civil Service reforms, the role and contribution of the Secretary of State and Permanent Secretary, and the nature of their relationship are provided to set the scene for the study reported. This is followed by the findings of an in-depth qualitative investigation highlighting how reading the Minister's mindset and emotional orientation are vital to positively engaging with the Secretary of State and winning their confidence. The paper concludes by identifying civil servant considerations to winning the Minister's confidence in order to facilitate effective and efficient policy delivery.

\section{Impact of Civil Service Reforms}

Gladstone, in 1870, chose to professionalize the civil service by implementing the NorthcoteTrevelyan recommendations in order to create 'neutral, permanent and anonymous officials motivated by the public interest; and a willingness to administer policies ultimately determined by Ministers' (Diamond, 2013: 42). This model characterized by a hierarchical mode of 
Weberian bureaucracy, remained essentially stable for a hundred years. However, in 1968 the Fulton Committee found civil service administrators as lacking in management skills. The system was reformed through unifying the grading system for all categories of staff, the creation of a Civil Service College and a central policy planning unit (The Fulton Report, 1968) and paved the way for the NPM movement of the 1980s. The NPM reforms transformed Public Administration from a core belief of public sector ethos and hierarchy as the means for resources allocation to that of efficiency, competition, and market mechanisms for resource allocation (Rhodes, 2016). Making the service-delivery aspects of government more 'businesslike' through establishment of various arms-length relationships highlighted the need for civil servants to 'master the skills for managing the complex, nonroutine issues, policies, and relationships in networks' (Rhodes, 2016: 641).

With such considerations the then Minister for the Civil Service, Francis Maude (2009), desired a smaller, more motivated, flexible, and business-like Civil Service. Maude's Civil Service Reform Plan (2012) recommended that Ministers have a 'stronger role' in the appointment of officials and Permanent Secretaries, and justified that by emphasizing the Ministers' direct accountability to Parliament for the delivery of policy priorities (HM Government, 2012; Rhodes, 2016). In effect, Maude wanted the Civil Service to operate more like a private sector entity, with increased accountability and a more entrepreneurial culture.

The ensuing Civil Service Reform Plan (HM Government, 2012) would have had far-reaching effects concerning the redefinition of the size and shape of the Civil Service and impact on civil servant career paths. Permanent Secretaries of delivery departments were expected to have at least two years' experience in a commercial or operational role, in order that a better balance be struck between those who had an operational management background and those who mainly provided policy advice (HM Government, 2012). 
Through his Reform Plan, Maude captured the sentiments held by certain Ministers towards civil servants: some felt they had limited control over the bureaucracy; others were undecided whether civil servant comment on Minister policy proposals was constructive advice or polite 'political sabotage' (Bardach and Patashnik, 2015: 123). Yet, despite Maude's exclamations, few Ministers interpreted the normal interdepartmental routines of policy delivery as obstructionist. On the contrary, a Freedom of Information (FOI) request found that the Cabinet Office had no records of such obstructionism (Paun et al, 2013: 12). In fact, civil servants have been criticized for being too accommodating to Ministers' wishes (HC, 2007) and for not arguing with sufficient vigour against questionable policy proposals (Butler et al, 1994).

Although some of Maude's (2012) initiatives such as centralized control and greater functional integration have to some extent been implemented, his greatest radical transformation has been to facilitate the UK becoming the second largest public sector outsourcing market in the world (Smith and Jones, 2015). The creation of cross-government functions - digital, commercial, HR - to deliver common services to all departments was a critical contribution.

\section{Secretary of State}

Since the end of the 17th century, ministerial responsibility has become the cornerstone of the Westminster system. Being the most senior minister and head of a department and/or ministry, the Secretary of State usually sits in the Cabinet. ${ }^{1}$

\footnotetext{
${ }^{1}$ The term 'Cabinet' dates from pre-revolutionary France and was the inner part of King Louis' bedroom. Only the most senior government officials were allowed to enter the cabinet. In the UK, it developed from the Privy Council in the 17th and early 18th centuries. The term 'Kitchen Cabinet' was first used to describe the coterie of close friends and political allies that formed around Harold Wilson in his first term (led by Marcia Williams, later Lady Falkender). Increasingly since then, it has been used to refer to the Number 10 'machine' as distinct from the Cabinet and Whitehall.
} 
Ministers have a duty to Parliament to account for and to be held to account for the policies, decisions, and actions of their departments and agencies, and hold office for as long as they have the confidence of the Prime Minister (Cabinet Office, 2011b; GOV.UK, 2018a).

As the political head of the department, the Minister is 'to answer to the legislature and through the legislature, to the public, both for his or her personal acts and for the acts of departmental subordinates' (Larson and Coe, 1999: 5). However, individual and collective ministerial responsibilities are largely realized through the Permanent Secretary (Kernaghan and Siegel, 1995). Thus, the quality of relationship between the Secretary of State and the Permanent Secretary is critical for the effective performance of the Secretary of State (Rhodes, 2011).

Since 2005, this critical relationship has been tested by Ministers' tenure of appointment, which has significantly decreased. By 2010, eleven out of nineteen departments (excluding HMRC) had experienced a change of Secretary of State (or senior minister in the case of the Cabinet Office) (Dash, 2012) on average, every 1.3 years (HC, 2007). Warning of the downside of short-term tenure, Tony Crosland revealed that it took at least two years for a Minister to become conversant with the core work and policy issues of a Department' (Ribbins and Sherratt, 2013: 106). Others concur and note that it takes time for the Minister to appreciate that the Civil Service is impartial and acts with honesty, objectivity, impartiality, and integrity, has a key constitutional function to perform, and is critical to delivering on the policies of the elected government (HCPASC, 2007; Cabinet Office, 2011a; 2011b).

Thus, the role of the Minister is multi-faceted. Ministers are elected representatives as well as MPs; they are members of their political parties; they represent their party in the media; they are members of the Cabinet; and are required to fully engage in the policies pursued and the outcomes being sought by the department (Broadbent, 1988). 


\section{Permanent Secretary}

Since the 19th-century foundation of the modern Civil Service, civil servants (including the administrative head of the department or Ministry, the Permanent Secretary) were and are considered as politically impartial and independent of government, and work in central government departments, agencies, and non-departmental public bodies (HCPASC, 2007). Despite the Permanent Secretary being a career civil servant who has tenure beyond the life of any particular government (Cabinet Office, 2011b), since May 2010, the turnover amongst 'permanent' secretaries has been substantial (Grube and Howard, 2016). For example, the Ministry of Defence (MOD), Cabinet Office, and Department for Transport (DfT) have each had four Permanent Secretaries (including acting heads of departments (GOV.UK, 2018b). The overall departmental average is two Permanent Secretaries in the two and a half years since the May 2016 election (excluding acting heads of departments; GOV.UK, 2018b). This compares with two Permanent Secretaries per department over the entire period from 1997 to May 2010 (excluding acting heads of department; GOV.UK, 2018b). Thus, the traditional view that 'the presentation of integrity, fearlessness, and independence of thought and utterance in their private communion with Ministers'. (Tomlin, 1931:1268) is considered to be slowly eroding (Hustedt and Salomonsen, 2014).

Irrespective of employment background, the Civil Service Management Code (Civil Service, 2015) set out the standards of behaviour expected of civil servants based on the values of integrity, honesty, objectivity, and impartiality. Moreover, it obliges them to 'serve the government of the day, whatever its political persuasion', to the best of their ability 'in a way which maintains political impartiality' (Civil Service, 2015: 1). The requirement is for civil servants to be appropriately responsive to the Secretary of State in offering advice on policy, systems, and processes as well as be proactive in working with the ministerial office and special advisers to clarify and efficiently pursue the Minister's priorities and preferences (Cabinet 
Office, 2018). Permanent Secretaries working with the Cabinet Secretary and Head of the Civil Service are collectively responsible for supporting proper and effective decision-making, the implementation of the government's cross-departmental and departmental priorities, and the exercise of the efficient use of resources (GOV.UK, 2016). Thus, the Permanent Secretary is required to be 'managing up' - engaging with the Secretary of State; 'managing down' leading his/her department, building capacity; and 'managing out' - engaging in network (meta-)governance (Van Dorp and 't Hart, 2019).

\section{Secretary of State and Permanent Secretary Relationship}

The traditional view of the public servant engagement with Ministers within the Westminster system, based on a clear separation of roles (Hughes et al, 2013), does not reflect actual practice or reality of their working relationship (Hughes et al, 2013). Svara (2001: 180) argues that the 'political-administration dichotomy' is a 'myth' and that the work is enacted through 'ongoing interaction, reciprocal influence, and mutual deference between elected officials and administrators'. Overeem (2012), on the other hand, suggests that the political-administrative dichotomy should be replaced by interdependence, complementarity, and bargaining.

Such adaptability, dependent on role-based discretion is seen as opportunity for manoeuvre, as rules and regulations will not provide appropriate guidelines for action or direction (Dworkin, 1978). Discretion and freedom requires the role holder to assess and to distinguish between relevant and non-relevant aspects in a situation and make considered appropriate decisions under conditions of uncertainty (Molander et al, 2012). The ability to effectively perform discretion and exercise good practical judgment requires one to integrate theoretical knowledge, practical skills, and deeply rooted values in order to be capable of functioning in a role that requires shaping and fine tuning (Kakabadse et al, 2009). 
As top civil servants, Permanent Secretaries hold high role-based discretion and, as such, significantly shape their department according to the circumstances they face and the organizational outcomes they consider appropriate (Riddell, 2014). As part and parcel of the role, the Permanent Secretary is the key link between the Minister and the service offered to the public (HCPAS, 2007). In this sense, senior public servants are the bridge between the political and managerial space and, as such, it is at their discretion how they address the ambiguity of being compliant or providing challenge, issue by issue, Minister by Minister. Both the Secretary of State and Permanent Secretary need to find ways through tensions between being in a position of authority and yet being circumscribed, formally and informally, by other stakeholders, such as the media, the constituency, the political party and the public, as well as institutional rules and protocols (Christensen and Opstrup, 2018).

Trust between the Secretary of State and the Permanent Secretary is of vital importance, but of itself is not sufficient (Haldenby et al, 2013). Effectively facilitating the involvement of other stakeholders, such as SpAds, has become an equal necessity.

Further, the recent churn of Secretaries of State and Permanent Secretaries has meant a 'lack of continuity and lack of collective memory' (HCPASC, 2013: 6). Commentators suggest that the length of tenure in the role is as important as the quality of the relationship between the two (Purnell and Lewis, 2012; Ribbins and Sherratt, 2014). Effectively adapting to changes of Secretaries of State and their priorities, which impact on the party, department, Cabinet, PM, Parliament, media, SpAds, constituents, and other stakeholders, has placed extensive pressure on the Permanent Secretary (Rutter, 2017; Cooper, 2019). Thus, shaping a sound working and supportive relationship between the Secretary of State and Permanent Secretary is recognized as demanding (Kakabadse and Kakabadse, 2011). 


\section{The Study}

In order to gain a wider perspective on the impact of the Secretary of State-Permanent Secretary relationship within the Westminster government system, the sampling frame for the study included senior officials and politicians. Eighty-one confidential interviews were conducted with Secretaries of State, junior ministers, SpAds, Permanent Secretaries, directors general (DGs) and other civil servants, NEDs on departmental boards, Chairs/CEOs of arm's length bodies and outsourcing contractors, examining the nature and contrasting experiences of the Secretary of State-Permanent Secretary relationship and its impact on policy delivery. Interviews were conducted between November 2017 and March 2018.

All interviews were undertaken on the condition of anonymity. The one-to-one in-depth interviews provided material that enabled us to analyse as well as theorize the nuance of the relationship between Secretary of State and Permanent Secretary.

Following data collection, a post-interview transcript analysis was pursued, encompassing a detailed search for underlying themes that was manually coded. All text was read several times and statements that appeared to be revealing about the phenomenon in question were highlighted (Van Manen, 1990). A detailed examination of the emergent thematic list enabled the recognition of regularities and patterns in the empirical material and the further categorization of these codes into sub-themes and grand themes (Denzin and Lincoln, 1994).

\section{Study Findings}

Data analysis revealed one overarching theme: the discretionary nature of the two roles of Secretary of State and Permanent Secretary; and two emergent characteristics that shape ministerial behaviour: preference for soft or hard evidence and a low or high level of personal confidence. The two dimensions - evidence preference and level of confidence - allowed for 
the building of an analytical model to scrutinize ministerial orientation; that is, mindset and resultant behaviour.

\section{Discretionary Leadership Roles}

Exercising discretion, be that judgement in decision-making or action to be taken, is already recognized as an essential part of the Secretary of State and Permanent Secretary roles (Williams, 1985). Discretion allows and demands flexibility when considering individual circumstances (Davis, 1969), where the ability to choose between options is at the core of discretion. However, the inherent concern with the high levels of discretion is that outcomes can be both positive and/or negative (Dillman, 2002). The Secretary of State in particular has considerable discretion limited only by the 'law, parliamentary support and, increasingly media coverage' (Van Dorp and 't Hart, 2019: 979).

The breadth of discretion available to the Secretary of State and Permanent Secretary emerged from this study as extensive. One Permanent Secretary emphasized the criticality of exercising discretion in terms of policy-making and delivery, that of enabling the government to realize its objectives.

'...shape the priorities of that government in a way that optimizes the chance that the government will be successful in delivering its goals on behalf of the people who've elected it.' (Permanent Secretary)

This was emphasized by Lord King (2006): 'we on the Nolan Committee made very clear that there should be discretion for Ministers, but the Ministers then had to take responsibility'. The focus here is on how Ministers balance their time and attention between prerogatives and priorities as well as duties (Gallagher and Laver, 1995; Andeweg, 2000). 
'Of course, I listen to views of officials and most times they are well thought through. But then I need to set direction and I state this is the way we are going even if that is opposite to the advice given. At the end of the day I decide.' (Secretary of State)

Officials supported this statement.

'Ministers rely on civil servants to provide the detailed information necessary for them to make informed decisions.' (Permanent Secretary)

Irrespective of the interests, responsibilities, and accountabilities that need to be reconciled, all participants in this study concurred that positively engaging with the Secretary of State is critical but demanding. Civil servants outlined the nature of the challenge to 'get onto the Minister's wave length' (Permanent Secretary) in order to navigate through the urgency versus realism tension. It was equally recognized that not only does the Permanent Secretary need to read the 'mind of the Minister', it is the Permanent Secretary who has to continually adapt to the Minister.

'I need to interpret what the politicians are trying to do, and then assist them to form the strategies which later impact on my Department.' (Permanent Secretary)

'My role requires me to facilitate the expressed wish of the Minister. They are the representatives of the people and we are to serve them and the people.' (Permanent Secretary)

'Devotion better describes the Permanent Secretary.' (Director General)

In fact, devotion to the Minister emerged as paramount in the mind and actions of Permanent Secretaries (Purnell and Lewis, 2012; Ribbins and Sherratt, 2014). 
Officials described considerable pressure of urgency to meet political goals facing the Secretary of State.

'I got it wrong and I had to say Minster [sic] we all let you down. I just did not read the situation well and the only one exposed is you, the Minister. I will not let her down again.' (Permanent Secretary)

Permanent Secretaries outlined that the focus of their discretionary judgement was to draw on their astuteness to handle situations of considerable tension, work through formal and informal boundaries, and be conscious of the political consequences of advice given and actions taken and/or resisted. Their aim was to read the Minister's orientation and through so doing build a relationship of respect.

'Some of my colleagues humble themselves. I more draw on the facts in front of me and been seen as confronting. Both approaches can work because the Minister realising his/her goals is all our concern.' (Permanent Secretary)

All interviewees concurred that the Minister's exposure to broad public accountability allowed for little sympathy to the slower, painstaking, but accurate scrutiny undertaken by the official of the policy landscape. Thus, the need is for the official to deeply understand the Minister and have them better engaged to work through the misaligned interests being faced, all to effectively deliver on policy.

\section{Engaging with the Secretary of State}

Effectively engaging with the Secretary of State emerged as the central consideration for how the respondents in this study utilized their discretionary choices. Irrespective of role and background, the study participants emphasized paying attention to how both the Minister drew on evidence and the Minister's level of personal confidence (or insecurity) deeply impacted 
their relationship. Hard evidence was defined as formalized communications, such as reports, accounting statements, opinion polls, which are detached and appear logical and objective (Mintzberg, 1994; Russell (1914). Soft data, on the other hand, was described as less formal information, such as feelings, opinions, 'how things are done around here', which certain consider subjective (Mintzberg, 1994).

Confidence at the level of the individual is the strength with which a person believes that a specific statement, opinion, or decision is the best possible they can offer and/or deliver (Peterson and Pitz, 1988; Zarnoth and Sniezek, 1997). The American psychologist and philosopher, James (2017), noted that few people succeed without a degree of confidence. Evidence indicates that when feeling confident, people develop more positive and productive relationships (Exworthy and Robinson, 2001).

These two characteristics - types of evidence and confidence levels - are identified by the study participants as driving four distinct patterns of orientation and behaviour, which impact the tension (positively or negatively) between the urgency of the Minister to execute policy and the realistic appraisal of the blockages and hindrances to policy execution undertaken by the civil servant (Figure 1). 


\begin{tabular}{|c|c|c|}
\hline & $\begin{array}{l}\text { Self absorbed } \\
\text { - Please me, } \\
\text { surrounds him/her } \\
\text { self with SpAds and } \\
\text { others who agree } \\
\text { - Opportunistic } \\
\text { agenda pursuit }\end{array}$ & $\begin{array}{l}\text { Rationalist } \\
\text { - Low need for SpAds } \\
\text { - Evidence based } \\
\text { agenda pursuit } \\
\text { - Open to comment }\end{array}$ \\
\hline & $\begin{array}{l}\text { Insecure } \\
\text { - Need SpAds to act as } \\
\text { shield and bolster } \\
\text { ego } \\
\text { - Self agenda pursuit } \\
\text { that is comfortable }\end{array}$ & $\begin{array}{l}\text { Communicator } \\
\text { - Relies on, gives } \\
\text { feedback, need } \\
\text { advice from SpAds } \\
\text { - Popularist agenda } \\
\text { pursuit }\end{array}$ \\
\hline
\end{tabular}

Figure 1: Minister orientation

\section{Self-absorbed}

Certain Secretaries of State were viewed by other Secretaries of State, junior ministers, civil servants, SpAds, Chairs, and CEOs of arm's length agencies as overly self-absorbed but displaying a discipline for drawing on hard data to enable decision-making.

'[Y]ou're trying to plan for literally the next three months, for the next six, for a year, and then beyond, and you've just got to keep all of that ticking over and trying to also instil a bit of your legacy in the department.' (Secretary of State)

The perceived or expressed lack of confidence was viewed as the reason for being overly self-conscious.

'I've got a very hyperactive Secretary of State, he's very ambitious, at times he is not sure of himself and that means that sometimes he gets frustrated at the pace of change that we're able to execute for him. How do we make him understand what's needed to deliver his policies in a way that he can have confidence?' (Permanent Secretary) 
Despite Ministers' preference for hard data, certain civil servants outlined that to capture a Minister's attention, presenting him/her in a positive light is critical.

I presented the facts and got thrown out of his office. Some time later I presented again but this time made sure the Minister looked good. The SpAd who was at the original meeting said, "But this is what you said the last time so why the positive response today?" I pointed out how this time the Minister could see his positive image shine through.' (Director General)

In order to realize positive engagement with Ministers displaying a self-absorbed orientation, civil servants report their focus is on the Secretary of State being viewed in a positive light. 'As long as he looks good', commented one Permanent Secretary, 'all else falls into place'.

\section{Insecure}

Ministers with low confidence and with a reliance on soft data are reported as tending to surround themselves with SpAds and others supportive of them to 'bolster their ego' (Secretary of State). It was reported that the Minister's insecurity and reliance on soft data leaves them overly dependent on the comment or opinion of the last person they met. Evidence-based conversations are acceptable if the Minister feels comfortable and receives acclaim.

'It's change again. Someone got to him [Secretary of State], made him feel good and that he would look good. We need to be even closer to him because what's next is not in his favour.' (Permanent Secretary)

Discussion that veers towards damage to the 'public interest' and/or making the tough decision likely generates defensiveness because the Minister's weaknesses become evident. 
'I still blame myself. I thought he/she [Secretary of State] was confident and outgoing and so I prepared public meetings and forums where he/she could shine. To my horror he/she was insecure and hated the big meeting. He/she likes small gatherings around him/her. To this day I am sure he/she has not forgiven me for leaving him/her feeling exposed and vulnerable.' (Director General; he/she is used in order to maintain confidentiality)

'... it's the insecurity that in all my experience of ministers is what makes them difficult to deal with. ... they're much more vulnerable to thinking that you might be trying to get one over on them, and that's the other thing that propels me to keep working at the relationship, because if there's a poor relationship with me then it's mисh harder for everyone else.' (Permanent Secretary)

Civil servants, SpAds, and certain NEDs on departmental boards described the lengths they go to to have the Minister feel comfortable. Paying attention to appropriately reading the Minister is backed by selective use of language, softness of tone, 'engineering settings where the Minister shines' (Director General), and not being economical with flattery. In fact, expressions of flattery and displays of loyalty are reported as critical to being trusted. Thus, unquestioning loyalty is a prime requirement to win the Minister's trust. If all else fails, then the imperative is to shield the vulnerabilities of the Minister from the public gaze.

\section{Communicator}

Civil servants, Chairs and CEOs of arm's length agencies, and departmental board NEDs described Ministers exuding confidence and who easily interrelate as reliant on soft data, informal conversation, 'chats at the bar' to build relationships. Yet, the informal nature of their interaction that puts others at ease does not always extend to honouring 
commitments made. Due to the affinities and emotional nature of interactions, the last person to see the Minister may be the one who wins the argument or their trust. Confident Ministers who effectively communicate through soft data rely on feedback concerning their impact on others. In this sense, SpAds are an invaluable source of opinion concerning the Minister's popularity and acceptability.

'I do let him know the impact he has made. Keeping him on track is not so easy as he gets caught up in the moment.' (SpAd)

Still, a change of mind on the Minister's part concerning opinions expressed on their views or their trust of others is commonplace.

'[Y]ou have Ministers saying to us, well we didn't mean exactly that, or they look a bit surprised that we've taken every word so seriously.' (Director General)

'I suppose people are worried about the reputational risk ... things are under considerable scrutiny.' (Secretary of State)

The approach adopted by civil servants, SpAds, and others to positively engage with the communicative Minister is to 'stay close to them' (SpAd). This was seen as 'not too onerous a task' (Permanent Secretary), as the confident and positive nature of the Minister made for easy and enjoyable interaction.

'Great to be with and you do not have to try too hard, just don't put too much trust to what he says.' (Permanent Secretary describing his interaction with a Minister)

\section{Rationalist}

In the eyes of civil servants, arm's length agency Chairs and CEOs, and departmental board NEDs, the ideal Minister is rational, evidence driven, high in confidence, has low need for 
SpAds or other aids and freely enters into debate. It is these ministers who show they are well able to accept and logically work through feedback and comment. At times their personal style may be too confrontational, but that is due to being evidence-driven and, as a consequence, less attentive to making others feel comfortable. The greatest criticism of SpAds and their political masters comes from the rationalist orientated Secretary of State. An intolerance for other Ministers who exhibit a lack of confidence was also forthcoming.

'Why all those SpAds around him? The reason is to protect him as he lacks confidence.' (Secretary of State describing another Secretary of State)

'Certain Ministers pick up knowledge very rapidly and some are capable of assimilating and retaining astonishing amounts of detail. They just do not suffer fools gladly.' (Permanent Secretary)

Civil servants in particular expressed their admiration for the rationalist Minister due to their capacity to think through the challenges they face, draw on evidence in order to construct a compelling argument, and encourage open and at times confrontational forms of communication, all to get to 'the heart of the matter'.

'It's hardly complexity. It's almost logic, reasoning, problem solving, judgement, but most of all drawing on evidence and analysis.' (Permanent Secretary)

'I was always quite keen to hear it, if I was talking nonsense or heading off in a foolish direction, I wanted to be told frankly, and occasionally I was and changed course and did something else.' (Secretary of State) 
Engaging with the rationalist Minister requires drawing on evidence in order to be focused on the task at hand.

'Whatever is required to do the job, that's me.' (Secretary of State)

'I just always took the view that there are a lot of very able people in the civil service, and I want their opinions.' (Secretary of State)

Although favoured and in certain cases held in awe by civil servants, NEDs, and Chairs and CEOs of arm's length agencies, the rationalist Minister was not so favoured by other Ministers. Their task orientation, disciplined and systematic approach to running meetings, and use of evidence left certain colleagues feeling inadequate, unable to contribute, or just 'cold'.

'He really puts people off, but knows how to drive things through. Surprised to hear you think he is good but I can see why you say that.' (Conversation with Chair of a Parliamentary Committee concerning a Secretary of State)

The rationalist Minister induced defensiveness and resentment more from other politicians than officials.

'I really had to do something. It was not the principle but his style. No patience and almost contempt for those who could not keep up'. (SpAd describing their involvement with their Secretary of State)

\section{Conclusion}

The challenge of realizing engagement across misaligned interests through the exercise of discretionary judgement is no new area of study. The Secretary of State-Permanent Secretary interrelationship displays similar characteristics to that of the Chairman-CEO relationship in 
third and private sector institutions (Kakabadse et al, 2010). The Chair's effective leadership of the board is vital in limiting unwelcome and self-seeking executive and director's influence (Kakabadse and Kakabadse, 2007). In order to provide for effective oversight, the Chair may adopt a control approach, which minimizes CEO entrenchment (Fama and Jensen, 1983; Mallette and Fowler, 1992). In contrast, a collaborative approach is rooted in stewardship, which focuses less on the risk of opportunism and more on the gains to be made from trust and co-operation (Davis et al 1997). Yet whichever approach is adopted, the 'chemistry' of the Chairman-CEO relationship is fundamental to effective board oversight of the enterprise and the management's capability to effectively pursue strategy.

Similar to the Secretary of State-Permanent Secretary relationship, the dual components of drawing on evidence and the emotionality underpinning confidence emerged from the study of the Chair-CEO relationship (Kakabadse et al, 2010). Whether private entities or government, in both contexts, the sensitivities and subtleties of the relationship have dramatic policy and strategy effects. It is a moot point as to which does greater harm: a relationship breakdown between the two, or them working through an ever-deteriorating relationship, not able or willing to speak 'truth to power'. It is little wonder that tension is inherent in these interactions. Determining the necessary steps to take for effective policy delivery, explicit and implicit negotiation of boundaries and the meeting of minds require continual attention. What is clear is that exercising discretion is vital for the purpose of adaptability and efficient decisionmaking.

The difference between the apex of a company and that of government is that the Chair-CEO relationship requires both to try to make it work (Kakabadse et al, 2006). In government and in contrast to the private/third sectors, it is clear that it is the Permanent Secretary who must be continually attentive to the Secretary of State to win their trust. Thus, in the context of a 'one- 
sided love affair', penetrating intellectual consideration is required to determine how to make the relationship function, followed by an exercise of deep sensitivity to win the Secretary of State's confidence. The study reported in this paper has revealed the efforts and lengths senior officials will go to in order for the Secretary of State to succeed, and be seen to succeed, in their delivery of policy. Such attentiveness hardly exists in any other institution.

Working through the challenges to effective policy delivery has officials display great concern for meeting the Minister's expectations and concerns. In fact, reading the Minister in order to adjust style, approach, and argument to be presented emerges as the most critical exercise of discretion. This study highlights that the accurate reading of the Minister involves consideration of their preference for type of evidence (soft or hard) and their level of confidence to publicly face up to and work through contingencies. Our findings also draw attention to the Permanent Secretary's painful and continuously self-regulating balancing act of responsiveness to the Secretary of State, often invisible to his/her political master. What is equally emphasized is that to 'misread the Minister' can easily lead to a breakdown of relationships, thus damaging policy delivery. In fact, the unspoken assumption was of civil servants' versatility of style to adjust according to what it takes to be on the Minister's wave length.

Overall, little evidence emerged that the Secretary of State appreciated the concern and deep level of service provided by the official for their Minister. The intellectual capabilities of senior civil servants are identified by Ministers as appreciated and respected. However, the lengths senior civil servants go to in order that the Secretary of State maintains the confidence of the public to lead through policy delivery is seemingly not recognized by the Minister. With little ministerial appreciation of the sensitivity necessary to engage across contrasting interests in 
order to effectively and efficiently deliver policy, the criticality of accurately 'reading the Minister' emerges as the paramount concern of the senior official. 


\section{References}

Andeweg, R.B. (2000) Ministers as double agents: The delegation process between cabinet and ministers. European Journal of Political Research 38: 377-395.

Aucoin, P. (2012) New political governance in Westminster systems: Impartial public administration and management performance at risk. Governance, 25(2): 177-199.

Bakvis H. (1997) Advising the executive: think tanks, consultants, political staff and kitchen cabinets. In: P. Weller, H. Bakvis, and R.A.W. Rhodes (eds) The Hollow Crown. Transforming Government. London: Palgrave Macmillan, pp. 84-125.

Bardach, E. and Patashnik, E. M. (2015). A Practical Guide for Policy Analysis: The Eightfold Path to More Effective Problem Solving, 5th edn. Washington, DC: CQ Press.

Barratt, E. (2015) Liberal conservatism, boardization and the government of civil servants. Organization 22(1): 40-57.

Blondel, J. (1985) Government Ministers in the Contemporary World. London: Sage.

Brazier, R. (1997) Ministers of the Crown. Oxford: Clarendon Press.

Broadbent, E. (1988) The Permanent Under-Secretary of State and His Department. In: Broadbent, E. (ed.) The Military and Government. New York: Springer, pp. 179-191.

Butler, D., Adonis, A. and Travers, T. (1994) Failure in British Government: The Politics of the Poll Tax. Oxford: Oxford University Press.

Cabinet Office (2011a) The Cabinet Manual: A Guide to Laws, Conventions and Rules on the Operation of Government (1st edn) October, Cabinet Office.

Cabinet Office (2011b), The Cabinet Manual, (1st edition) October, https://assets.publishing.service.gov.uk/government/uploads/system/uploads/attachment _data/file/60641/cabinet-manual.pdf accessed 5 February 2019.

Cabinet Office (2018) Ministerial Code, May 2018, http://webarchive.nationalarchives.gov.uk/+/http:/www.cabinetoffice.gov.uk/media/409 215/ministerialcodemay2018.pdf accessed 25 October 2018.

Chapman, R.A. (2004) The Civil Service Commission 1855-1991: A Bureau Biography. London: Routledge.

Christensen, J. G. and Opstrup, N. (2018). Bureaucratic dilemmas: Civil servants between political responsiveness and normative constraints. Governance, 31(4): 481-498.

Christensen, T. and Lægreid, P. (2012) Competing principles of agency organization - the reorganization of a reform. International Review of Administrative Sciences 78(4): 579596.

Civil Service (2015) Civil Service code, 16 March 2015, https://www.gov.uk/government/publications/civil-service-code/the-civil-service-code accessed 10 March 2019.

Cooper, C.A. (2019) Politics and the permanency of permanent secretaries: testing the vitality of the Westminster administrative tradition, 1949-2014. British Politics, https://doi.org/10.1057/s41293-019-00113-8 accessed 10 May 2019, pp 1-15.

Cowley, P. and Melhuish, D. (1997) Peers' careers: Ministers in the House of Lords, 1964-95. Political Studies 45(1): 21-35. 
Cunnigham, C. (1963) Policy and practice. Public Administration 41(3): 229-238.

Dash, K (2012) Permanent secretaries? Institute of Government, 12 November, https://www.instituteforgovernment.org.uk/blog/permanent-secretaries accessed 28 March 2019.

Davis, J.H., Schoorman, F.D., and Donaldson, L. (1997) Toward a stewardship theory of management. Academy of Management Review 22(1): 20-47.

Davis, K.C. (1969) Discretionary Justice. Baton Rouge, LA: Louisiana State University Press.

Denzin, N. and Lincoln, Y. (eds) (1994) Handbook of Qualitative Research. Thousand Oaks: Sage.

Diamond, P. (2013) Governing Britain: Power, Politics and the Prime Minister. London: I.B. Tauris.

Diamond, P. (2019) Breaking the Mould? Roy Jenkins' 'RadicalCentre' and British Social Democracy in the 'New Hard Times'. The Political Quarterly 90 (1): 134-142.

Dillman, D.L. (2002) The paradox of discretion and the case of Elian Gonzalez. Public Organization Review: A Global Journal 2(2): 165-185.

Donnelly, M. (2014) Speech to the Institute of Government. Institute for Government: London.

Dworkin, R. M. (1978) Law's Empire, New edition. Oxford: Hart Publishing.

Exworthy, M. and Robinson, R. (2001) Two at the top: relations between Chairs and Chief Executives in the NHS. Health Services Management Research 14(2): 82-91.

Fama, E.F. and Jensen, M.C. (1983) Separation of ownership and control. Journal of Law and Economics 26(2): 301-325.

Gallagher, M.M. and Laver, P.M. (1995) Representative Government in Modern Europe. New York: McGraw-Hill.

GOV.UK (2016) Civil Service Leadership Statement. 25 August 2016, https://www.gov.uk/government/publications/civil-service-leadership-statement/civilservice-leadership-statement accessed 3 February 2019.

GOV.UK (2018a) Cabinet ministers, https://www.gov.uk/government/ministers accessed 10 March 2019.

GOV.UK (2018b) Ministerial appointments: January 2018. 9 January 2018, https://www.gov.uk/government/news/ministerial-appointments-january-2018 accessed 10 March 2019.

Greer, S. and Jarman, H. (2010) Definitions, demographics and the changing home Civil Service. Public Policy and Administration 25(3): 251-270.

Grube, D. (2015) Responsibility to be enthusiastic? Public servants and the public face of 'promiscuous partisanship'. Governance 28(3): 305-320.

Grube, D.C. and Howard, H. (2016) Is the Westminster system broken beyond repair? Governance 29(4): 467-481.

Haldenby, A., Majumdar, T. and Rosen, G. (2013) Whitehall reform: The view from the inside, February, Reform Research Trust, http://www.reform.co.uk/resources/0000/0607/Whitehall_reform_The_view_from_the_ inside.pdf accessed 18 April 2019. 
Haldenby, A., Majumdar, T. and Rosen, G. (2013) Whitehall reform: The view from the inside, February, Reform Whitehall, www.reform.co.uk accessed 20 October 2019.

Hambrick, D.C. and Finkelstein, S. (1987) Managerial discretion: A bridge between polar views on organizations. In: L.L. Cummings and B.M. Staw (eds.), Research in Organizational Behaviour, Vol. 9. Greenwich, CT: JAI Press, pp.369-406.

HC (House of Commons) (2007) Public Administration - ninth report - the influence of ministers, 24 July,

https://publications.parliament.uk/pa/cm200607/cmselect/cmpubadm/93/9302.htm accessed 10 April 2019.

HCPASC (House of Commons Public Administration Select Committee) (2013) Truth to power: how Civil Service reform can succeed, eighth report of session 2013-14 Volume I: Report, together with formal minutes, oral evidence, House of Commons, 6 October, https://publications.parliament.uk/pa/cm201314/cmselect/cmpubadm/74/74.pdf accessed 14 April 2019.

HCPASC (House of Commons Public Administration Select Committee) (2007) Politics and administration: Ministers and civil servants, third report of session 2006-07, HC 122-I, 26 March 2007.

HCPASC (House of Commons Public Administration Select Committee), (2007), Politics and Administration: Ministers and Civil Servants, HC 122-I, 26 March, https://publications.parliament.uk/pa/cm200607/cmselect/cmpubadm/122/122i.pdf accessed 15 February 2019.

HM Government (2012) The Civil Service Reform Plan, https://www.gov.uk/government/publications/civil-service-reform-plan, accessed 7 February 2019.

Hughes, O., Alford, J., and Hartley, J. (2013) Into the purple zone: Interactions between senior civil servants and political leaders, International Research Symposium on Public Management, Prague, 10-12 April.

Hustedt, T. and Salomonsen, H.H. (2014) Ensuring political responsiveness: politicization mechanisms in ministerial bureaucracies. International Review of Administrative Sciences 80(4): 746-765.

James, W. (2017) The Principles of Psychology, Vols 1-2, CreateSpace Independent Publishing Platform: Combined edition.

Jary, C. (2015) Working with ministers, Civil Service Policy profession. http://www. civilservant.org.uk/library/2015_Working_with_Ministers.pdf (Accessed; 20.02.2020).

Jennings, Sir I. (1952) The Law and the Constitution, 2nd edn. London: The University of London Press.

Kakabadse, A., Kakabadse, N., and Barratt, R. (2006) Chairmen and chief executive officer: That sacred and special relationship. Journal of Management Development 25(2): 134150.

Kakabadse, A.P. and Kakabadse, N.K. (2011) Eleven sides to the minister of the crown. British Politics 6(3): 345-378.

Kakabadse, A.P., Kakabadse, N.K., and Knyght, R. (2010) The chemistry factor in the Chairman/CEO relationship. European Management Journal 28(4): 285-296. 
Kakabadse, N., Davies, L-L. and Kakabadse, A. (2009) Leadership discretion: a developmental experience, Strategic Change, 18(1): 111-124.

Kakabadse, N.K and Kakabadse, A.P. (2007) Chairman of the board: demographics effects on role pursuit. Journal of Management Development 26(2): 169-192.

Kernaghan, K and Siegel, D. (1995) Public Administration in Canada. Scarborough, ON: Nelson Canada.

King, L. (2006) Oral evidence taken before the Committee, House of Commons, 16 March, HC 884-iii.

Kogan, M. (1971) The Politics of Education. Harmondsworth, UK: Penguin.

Larson, P.E and Coe, A. (1999) Managing Change: The Evolving Role of Top Public Servants, Strategies for Improvement Series No. 7, Commonwealth Secretariat.

Mallette, P. and Fowler, K.L. (1992) Effects of board composition and stock ownership on the adoption of 'poison pills'. Academy of Management Journal 35(5): 1010-1035.

Maude in HM Government (2012) The Civil Service Reform Plan. http://www.civilservice.gov.uk/wp-content/uploads/2012/06/Civil-Service-ReformPlan-accfinal.pdf accessed 27 February 2018.

Maude, F. (2009) Speech to Civil Service World Conference, Westminster, London, 11 November, www.francismaude.com/newsshow.aspx?id=24\&ref=63 accessed 20 November 2014.

McMaster, A. and Bairner, A. (2012) Junior ministers in the UK: the role of the minister for sport. Parliamentary Affairs 65(1): 214-237.

Mintzberg, H. (1994) Rise and Fall of Strategic Planning. London: Simon and Schuster.

Molander, A., Grimen, H., and Eriksen, E.O. (2012) Professional discretion and accountability in the welfare state. Applied Philosophy, 29(3): 214-230.

Morrison, H. (1954) Government and Parliament: A Survey from the Inside. Oxford: Oxford University Press.

Overeem, P. (2012). The Politics-Administration Dichotomy: Toward a Constitutional Perspective. New York: CRC Press.

Paun, A., Harris, J. and with Magee, I.S. (2013) Permanent Secretary Appointments and the Role of Ministers. London: Institute of Government.

Peters, G.B. (2013) Politicization: What is it and why should we care? In: Neuhold, C., Vanhoonacker, S., and Verhey, L. (eds) Civil Servants and Politics: A Delicate Balance, Basingstoke and New York: Palgrave Macmillan, pp. 12-24.

Peterson, D.K. and Pitz, G.F. (1988) Confidence, uncertainty, and the use of information. Journal of Experimental Psychology: Learning, Memory, and Cognition 14: 85-92.

Purnell, J. and Lewis, L. (2012) Leading a Government Department: The First 100 Days. London: Institute for Government.

Rhodes, R. (2011) Everyday Life in British Government. Oxford: Oxford University Press.

Rhodes, R.A.W. (2016) Recovering the Craft of Public Administration, Public Administration Review, 76(4): 638-647. 
Ribbins, P. and Sherratt, B. (2013) The permanent secretary as policy-maker, shaper, taker, sharer, and resister in education - reflections on Sir James Hamilton as a centralising outsider. Journal of Educational Administration and History, 45(1): 28-48.

Ribbins, P. and Sherratt, B. (2014) Reforming the Civil Service and revising the role of the mandarin in Britain: A view from the perspective of a study of eight permanent secretaries at the Ministry of Education between 1976 and 2011. Public Policy and Administration 29(1): 21-44.

Richards, D. (1997) The Civil Service under the Conservatives 1979-1997. Brighton, UK: Sussex Academic Press.

Riddell, P. (2014) Ministers and Mandarins How Civil Servants and Politicians Can Work Better Together, Institute of Government, https://www.conservativehome.com/platform/2013/10/from-_peterriddell-ministersand-mandarins-how-politicians-and-civil-servants-can-work-better-together.html, accessed 3 February 2018.

Russell, B. (1914) Knowledge of the External World as a Field for Scientific Method in Philosophy. Chicago and London: Open Court Publishing.

Rutter, J. (2017) Churn at the Department for Exiting the EU looks set to accelerate, Institute of Government, 20 December, https://www.instituteforgovernment.org.uk/blog/churndexeu-brexit-civil-service-accelerate accessed 10 May 2019.

Seddon, J. (2014) The Whitehall Effect: How Whitehall Became the Enemy of Great Public Services and What We Can Do About it. Bridport, UK: Triarchy Press.

Smith, M.J. and Jones, R. (2015) From big society to small state: Conservatism and the privatisation of Government. British Politics 10(2): 226-248.

Svara, J. (2001) The myth of the dichotomy: Complementarity of politics and administration in the past and future of public administration. Public Administration Review 61: 176183.

The Fulton Report (1968) The Civil Service, Report of the Committee 1966-68, Chairman: Lord Fulton. London: Her Majesty's Stationery Office, London.

Theakston, K. (1999) Leadership in Whitehall. Basingstoke: Palgrave Macmillan.

Theakston, K. and Fry, G. (1989) British administrative elite: permanent secretaries 1900-86. Public Administration 67(2): 129-147.

Waldo, D. (1948). The Administrative State. New York: Ronald Press Company.

Wallas, G. (1920) Human Nature in Politics, 2nd edn. London: Constable.

Waller, P. (2014) Political advisors and policymaking process. In: Young, B. and Hazell, R. (eds), Special Advisors: Who They Are, What They Do and Why They Matter. Oxford: Hart Publishing, pp. 111-127.

Weber, M. (1922) The Theory of Economic and Social Organization, vols I and II, edited by G. Roth and C. Wittich, Berkeley: University of California Press.

Wildavsky, A. (1979) Speaking Truth to Power: The Art and Craft of Policy Analysis. New York: Little Brown.

Williams, G.H. (1985) The politics of police discretion. In: C. Pinkele and W. Louthan (eds) Discretion, Justice, and Democracy. Ames, Iowa: The Iowa State University Press, pp. 19-30. 
Zarnoth, P. and Sniezek, J.A. (1997) The social influence of confidence in group decision making. Journal of Experimental Social Psychology 33: 345-366. 